\title{
Rho Guanine Nucleotide Exchange Factor 2
}

National Cancer Institute

\section{Source}

National Cancer Institute. Rho Guanine Nucleotide Exchange Factor 2. NCI Thesaurus.

Code C101782.

Rho guanine nucleotide exchange factor 2 (986 aa, $112 \mathrm{kDa}$ ) is encoded by the human ARHGEF2 gene. This protein is involved in the regulation of both guanine nucleotide exchange and signal transduction. 